\title{
Gesag as diens: Die rol van die dissipels in die Matteusevangelie
}

\author{
Author: \\ Hermie C. van $\left.Z y\right|^{1}$ \\ Affiliation: \\ ${ }^{1}$ Department of New \\ Testament, University of the \\ Free State, South Africa \\ Correspondence to: \\ Hermie van Zyl \\ Email: \\ vzylhc@ufs.ac.za \\ Postal address: \\ PO Box 339, Bloemfontein \\ 9300, South Africa \\ Dates: \\ Received: 14 Apr. 2011 \\ Accepted: 14 Sept. 2011 \\ Published: 22 Feb. 2012 \\ How to cite this article: \\ Van Zyl, H.C., 2012, 'Gesag as \\ diens: Die rol van die dissipels \\ in die Matteusevangelie', \\ HTS Teologiese Studies/ \\ Theological Studies 68(1), Art. \\ \#1064, 8 pages. http://dx.doi. \\ org/10.4102/hts.v68i1.1064
}

\begin{abstract}
Authority as service: The role of the disciples in the Gospel according to Matthew. This article juxtaposes authority and service in the Gospel of Matthew. Firstly the article refers to the transfer of authority from Jesus to the disciples. Several relevant texts are discussed, including Matthew's employment of proserchomai. Secondly the content of this authority is examined. The emphasis falls on the teaching authority of the disciples, especially to forgive sins. Thirdly the nature of authority is treated. It is not about lording it over people but to serve the believers in humility. In a last section all of the above is viewed against the backdrop of the first century Matthean community's struggle to find its place within formative Judaism. The thesis is put forward that Matthew propounds a voluntary marginality, according to which the reader should take upon him- or herself the position of the poor.
\end{abstract}

\section{Inleiding}

Dat die kwessie van Jesus en die dissipels se gesag belangrik is vir die Matteusevangelie blyk uit die slottoneel, Matteus 28:16-20. Jesus roep die dissipels byeen op 'n berg in Galilea, en nadat Hy verklaar het dat alle gesag (eksousia) in hemel en op aarde aan Hom gegee is, beklee Hy die dissipels met dieselfde gesag deur aan hulle die opdrag te gee om dissipels van al die nasies te maak, hulle te doop in die Naam van die Vader, Seun en Heilige Gees, en hulle te leer om alles te onderhou wat Hy hulle beveel het. Daarna volg die belofte van Jesus se teenwoordigheid tot by die einde van die wêreld.

Verskeie Matteus-navorsers wys op die belangrikheid van hierdie slottoneel (Smith 1993; Krentz 2004:24; Brooks 1981; Perkins 1993:574, 587-588; Lee 2010:14, 22). Al die hooftemas van die Matteusevangelie word hier saamgetrek: gesag van Jesus, gesagsoordrag aan die dissipels, dissipelskap van al die nasies, Jesus se onderrig en die bewaring daarvan, en Jesus se teenwoordigheid in sy kerk. In hierdie verband is Luz se opmerking insiggewend: 'It is my belief that this passage ... is entirely redactional. Every word of it counts; it abounds in associations with earlier passages' (Luz 1995:139). Dit is dus geregverdig om op die tema van Jesus en die dissipels se gesag, as een van Matteus se hooftemas, te fokus.

Omdat die gesag van Jesus en van die dissipels in die Matteusevangelie so verweef is, sal in hierdie bydrae hoofsaaklik gekonsentreer word op die gesag van die dissipels - hoe Jesus se gesag aan die dissipels oorgedra word, wat die inhoud en aard daarvan is, en hoe dit binne die konteks van die Matteaanse geloofsgemeenskap geïnterpreteer moet word.

\section{Gesagsoordrag aan die dissipels}

Dit wil voorkom asof Matteus sekere gebeure so opteken dat die klem val op die voortgaande gesag van Jesus in die Matteaanse gemeente, of, anders gestel, dat die gesag van die dissipels, en daarmee die Matteaanse gemeente, beklemtoon word. Dit het waarskynlik te make met die feit dat die opvolgers van die dissipels in die tyd van die Matteaanse gemeente, ongeveer vyftig jaar na die werklike gebeure, as die voortsetting van Jesus se gesag beskou is (Reese 1977:140-141). Die dissipels in Matteus word dus so geteken dat hulle as transparante rolmodelle kan dien vir die gemeente van Matteus se gesag (vgl. Luz 1980:377). Die volgende gedeeltes is belangrik in dié verband.

\section{Die genesing van die verlamde man (Matt 9:1-8)}

Die genesing van die verlamde man in Matteus 9:1-8 het parallelle in Markus 2 en Lukas 5, maar uniek aan Matteus is die reaksie van die skare in vers 8. Hoewel al drie Evangelies meld dat die omstanders oorstelp was oor die genesing van die verlamde, is Matteus se bewoording hiervan uniek. Slegs hy meld dat die skare God verheerlik het 'wat soveel gesag (eksousia) aan mense gee'. Volgens Markus en Lukas lyk dit asof die omstanders bloot in vervoering is oor die genesing, maar by Matteus lê die klem elders, naamlik op die feit dat God gesag aan mense gee. Hoewel 
dit Jesus was wat die genesing gedoen het, veralgemeen Matteus die gesag en verplaas dit na die mense. Kennelik het Matteus 'n ander, post-aardse-Jesus scenario in die oog, naamlik sy gemeentesituasie waar daar leiers - mense - is wat met Jesus se gesag optree (Luz 1996:38). Verder tree ook 'n ander aspek na vore. Volgens Matteus is die verbasing nie soseer oor die genesing nie, maar oor die sondevergiffenis wat daarmee geassosieer word. Dit dui waarskynlik op Matteus se situasie waar sondevergiffenis 'n belangrike aspek van die gemeentelike lewe uitgemaak het (later meer hieroor). Die gemeente verwonder hulle daaroor dat hulle deel in die Goddelike gesag om sondes te vergewe. Daarom benut Matteus die tradisie van die genesing van die verlamde om nie net die gesag van Jesus wat genees en sondes vergewe weer te gee nie, maar terselfdertyd om die gesag van die Matteaanse gemeente om sondes te vergewe, te substansieer. In hierdie verhaal vind daar dus 'n subtiele gesagsoordrag plaas van Jesus na Matteus se gemeente.

\section{Slottoneel (Matt 28:16-20)}

Soos reeds in die inleiding genoem, bestaan die laaste toneel van Matteus (Matt 28:16-20) uit 'n kulminasie van die belangrike temas in die Evangelie, onder andere die oordrag van gesag aan die dissipels. In 'n interessante studie het Edwards (1987) gewys op die belang van die term proserchomai in die oordrag van gesag. Hy toon uitvoerig aan hoe hierdie term in die LXX kultiese konnotasies het, en waarskynlik deur Matteus uit hierdie sfeer oorgeneem word om op verskillende plekke in sy Evangelie aan te toon dat Jesus die objek van menslike verering en aanbidding is (bv. Matt 8:2, 19, 25; 9:14, 18; 13:10; 17:19; 18:1; 19:16; 20:20). Soos die altaar, priester of Moses in die Ou Testament die locus van God se teenwoordigheid en handeling was, so is Jesus dit in die nuwe verbond. Matteus wend dus hierdie kulties gelade term aan om Jesus se Messiaanse identiteit te onderstreep.

Daar is egter twee gevalle in Matteus waar Jesus nie die objek nie, maar die subjek van proserchomai is, naamlik op die berg van verheerliking (17:7) en na sy opstanding (28:18). In beide gevalle is dit Hý wat die dissípels nader, en nie andersom nie. Die vraag is of dit toevallig is, en of dit doelbewus so voorgestel word. Gegewe die verhoogde insidensie van proserchomai in Matteus, die waarskynlik kultiese aanwending van hierdie term met Jesus as objek, die feit dat Matteus teenoor Markus dit vermy om Jesus as subjek van proserchomai te gebruik, en die kontekstuele ooreenkomste tussen Jesus wat die dissipels nader op die berg van verheerliking en op die berg van ontmoeting in Matteus 28, moet ons waarskynlik 'n bedoelde redaksionele bewerking van Matteus hier aanvaar. ${ }^{1}$

Indien hierdie aanname korrek is, wat sou die bedoeling wees? In beide gevalle gee Jesus opdragte - in Matteus 17 dat die dissipels die messiaanse visioen geheim moet hou, en in Matteus 28 die opdrag om dissipels van die nasies te maak.

1.Uiteraard vind die gebeure op die berg van verheerliking vóór Jesus se opstanding plaas, maar volgens Edwards (1987:73, voetnoot 22) is hierdie gebeure verwant aan die opstanding, want in 17:9 staan daar dat Jesus die dissipels opdrag gegee het om nie oor die visioen op die berg van verheerliking te praat voordat die Seun van die mens opgewek is uit die dood nie. Wat die dissipels dus op die berg ervaar het, was mens opgewek is uit die dood nie. Wat die dissipels dus op die berg
Vóór die opstanding het die dissipels vir Jésus genader, maar nou, na sy opstanding (Matt 28), tree daar 'n verandering in die verhouding tussen Jesus en die dissipels in. Hy is nou die verhoogde Here wat sy dissipels nader om hulle te bemagtig (eksousia oor te dra) vir hulle taak. Waar die dissipels voorheen by Jésus moes bly, is Hy nou by húlle tot aan die voleinding van die wêreld. Die verandering in verhouding tussen Jesus en die dissipels is dat die dissipels nou nie meer bloot ondergeskiktes is nie, maar 'eweknieë' of 'vennote' in Jesus se wêreldwye bediening. Hierdie verandering in status word ook gesuggereer deur die feit dat ná die opstanding die dissipels nou 'broers' (adelfoi) genoem word (Matt 28:10). Op hierdie manier wil Matteus aantoon dat die dissipels - en so, die kerk - met gesag beklee word vir Jesus se messiaanse taak in die wêreld.

\section{Die rots waarop die kerk gebou sal word (Matt 16:17-19)}

Een van die belangrike plekke van gesagsoordrag in die Matteusevangelie is Matteus 16:17-19. Die persoon van Petrus, as verteenwoordiger van die dissipels, ontvang hier besondere klem. Hierdie verse is Matteaanse Sondergut, en bevat Jesus se reaksie op Petrus se belydenis in Matteus 16:16 (par Mark 8:29//Luk 9:20) dat Jesus die Christus, die Seun van die lewende God is. Daar is twee momente in Jesus se reaksie: In 'n woordspeling op Petrus se naam word gesê dat Jesus sy kerk op hierdie rots sal bou, en dat die magte van Hades dit nie sal oorweldig nie, en aan Petrus word die sleutels van die koninkryk oorhandig: wat hy op aarde bind of ontbind, sal in die hemel gebind of ontbind wees (Overman 1990:136-139).

Petrus se posisie in Matteus word nie so oordryf dat hy 'n onrealistiese of 'plat' karakter word nie (kyk §4). Tog is Petrus in Matteus nie bloot een van die dissipels nie. Hy word 'n soort primus inter pares (Kingsbury 1979:71). Hy is die eerste wat as dissipel geroep word (Matt 4:18), Matteus voeg die woord prōtos in by sy naam wanneer die dissipels gelys word (Matt 10:2), en hy ontvang spesiale onderrig oor halakiese kwessies (Matt 15:15; 17:24-27; 18:21).

Die twee beelde van 'rots' en 'sleutels' in Matteus 16:18-19 verdien kortliks meer aandag. Matteus gebruik 'rots' elders (Matt 7:24) om die gesag en waarheid van Jesus se onderrig as die basis van die lewe uit te druk. Wie hom daarop verlaat, bly behoue; wie dit misken, is gedoem tot ondergang. Ook in Koemraan word 'rots' gebruik om die waarheid van God, en die Koemraangemeenskap as die ware Israel te beskryf (Overman 1990:137). Dit is dus 'n merkwaardige ontwikkeling as Matteus hierdie term aan 'n persoon koppel. Petrus is nou die rots of fondasie van die koninkryk. Uiteraard gaan dit nie net oor die persoon van Petrus nie, maar oor die feit dat die waarheid deur God aan hom geopenbaar is (Matt 16:17). Daarom is hy en sy belydenis die fondasie waarop die gemeente rus, en bied dit 'n skans teen alle opposisie, selfs teen die laaste vyand, die dood. ${ }^{2}$ So word Petrus, en deur 2.Die pulai hadou [poorte van die doderyk] van Matteus 16:18 het in Joodse en Griekse konteks verwys na die mag van die dood (vgl. Keener 1999:428-429). 
hom die dissipels en die Matteaanse gemeente, die garant van die regte verstaan en onderrig van die wil van God.

Dieselfde gedagte kan min of meer gekoppel word aan die beeld van die sleutels. Laasgenoemde is na alle waarskynlikheid aan Jesaja 22:22 ontleen (Carson 1984:370). In hierdie vers is dit ' $n$ beeld van gesagsoordrag aan Eljakim, aan wie die mag gegee word om te regeer, om oop en toe te sluit. In 2 Barug 10:18 en 4 Barug 4:4 - geskrifte min of meer uit die tyd van Matteus - word dieselfde beeld gebruik om die gesag oor die tempel van die priesters terug te verplaas na God toe (Overman 1990:138). Dit is dus duidelik dat die beeld van die sleutels 'n simbool van gesag en van Goddelike seën en sanksie was. Wie in besit van die sleutels was, kon aanspraak maak op Goddelike gesag; hulle was inderdaad verteenwoordigers van Goddelike gesag op aarde.

Matteus verstaan dit dus so dat met hierdie oordrag van sleutelmag Petrus die verteenwoordiger word van die gesag en mag van die koninkryk van die hemele op aarde. Hy ontvang die mag om op aarde bindende besluite te neem. Wat hy 'op aarde', dit wil sê, in die gemeente besluit, het ook gevolge vir die toekoms, die hemel. Aan Petrus word die gesag gegee om die deurwagter of bewaker te wees, beide van die kerk op aarde én eskatologies, in die hemel.

\section{Die inhoud van die gesag}

Volgens Matteus 28:19-20 word aan die dissipels of Matteaanse kerk die taak gegee om dissipels van al die nasies te maak. Dit is die hoofopdrag (vgl. die aor imperatief van mathēteūo). Die wyse waarop dit gedoen word, is onder meer om die nasies alles te leer $\left(\right.$ didask $\left.^{3}\right)$ wat Jesus beveel het. Hieruit kan ons sê dat die gesagsoordrag waarvan in die vorige hoofpunt sprake was, hoofsaaklik met onderrig te make gehad het; die gesagsoordrag het as inhoud leergesag. En hierdie leergesag rus op sy beurt op die gesagvolle onderrig van Jesus. Jesus het die wet van Moses op ' $n$ bepaalde manier verstaan en uitgelê, 'n interpretasie wat meer gesag ingeboesem het as dié van die skrifgeleerdes van die Jode (vgl. Matt 5:17; 7:28-29), en dit is hierdie interpretasie wat die basis en waarborg vorm van die gesag waarmee die dissipels optree.

Dat die klem in Matteus veral op die leergesag van die disspels val, word gestaaf deur ' $n$ interessante tekstuele waarneming (vgl. Overman 1990:126-130). Téénoor Markus en Lukas word Jesus - en daarmee die dissipels - se bewegings deur Matteus geografies ingekort. Die Evangelie volgens Markus stel Jesus voor as die Messias 'op weg' (en tē hodō), veral in sy sentrale gedeelte, te wete Markus 8:22-10:52. Hierdie mobiele en rondtrekkende Jesus - wat 'n redaksionele kenmerk van Markus is - word konsekwent deur Matteus weggelaat. Ons vind by Matteus eerder 'n konsentrasie van Jesus se leerarbeid in Galilea. So begewe Matteus se Jesus Hom nooit in Samaritaanse gebied nie, anders as in Lukas. En die reis deur Dekapolis van Markus 7:31 word deur Matteus 15:29 weggelaat en beperk tot ' $n$ berg by die See van Galilea, waar die mense dan na Hóm toe kom. Matteus vermeld wel 'n 3.Didaskö is' $n$ begeleidende partisipium by mathëteuō. bediening aan Dekapolis, maar weer eens op so 'n wyse dat die mense uit hierdie gebied na Hóm toe kom (Matt 4:25). Matteus se fokus op Galilea kan nog verder verbesonder word tot Kapernaum. Slegs Matteus vermeld dat Jesus in Kapernaum gewoon het (katoikeō; Matt 4:13), en dat dit 'sy eie dorp' was (eis tēn idian polin; Matt 9:1). Die dissipels se bewegings word ook saam met Jesus s'n aan bande gelê. Volgens Matteus waag die dissipels dit nie uit op hulle eie, soos in Markus 6:12 en 30 nie. Hulle bly eerder by Jesus om so onderrig te word omtrent die koninkryk.

Die geografiese inkorting van Jesus en sy dissipels se bewegings verhoog die residerende en onderrigtende aard van hulle bediening. Hulle is die leermeesters wat met gesag beklee is, na wie die mense opsien en na wie hulle kom vir leiding en gesagvolle onderrig omtrent die koninkryk van die hemele. Die klem op die leergesag van die dissipels blyk ook duidelik, soos reeds genoem, uit die finale opdrag aan die dissipels in Matteus 28:16-20. Hulle word nie met gesag beklee om siekes te genees, demone uit te dryf, of die dooies op te wek nie, maar om mense te onderrig omtrent Jesus se opdragte.

Dekades later is hierdie gegewens transparant vir die Matteaanse gemeente. Hulle vind as't ware hulle eie situasie terug in die Matteusevangelie. Soos die mense na Jesus toe gekom het om na sy onderrig te luister, so kom die Matteaanse gemeente na hulle leiers toe. Soos die dissipels deur Jesus opgelei is vir hulle taak as leraars in die koninkryk van God, so is die leiers in die gemeente nou besig om die gelowiges te onderrig sodat hulle kan konformeer aan die norme van die koninkryk, want slegs so kan hulle ware dissipels wees.

Om mense te onderrig moet die dissipels ook self goeie luisteraars en begrypers wees. Hulle moet die geheime en norme van die koninkryk verstaan. In die lig hiervan is dit te verstane dat Matteus die neiging by Markus om die dissipels in 'n negatiewe lig te stel, neutraliseer (Luz 1980:382). So laat hy Markus 9:6, 10 en 32 weg, waar die dissipels se gebrek aan begrip omtrent die taak en identiteit van Jesus genoem word. Omgekeerd voeg Matteus gedeeltes by waar beskryf word dat die dissipels oë en ore het om die geheime van die koninkryk te begryp (Matt 13:16-17), en dat hulle 'al hierdie dinge' verstaan (Matt 13:51). Die term 'kleingelowiges', 'n voorkeurterm van Matteus vir die dissipels, dra ook by om die harde opmerkings van Markus oor die dissipels se ongeloof te versag (bv. Matt 8:26//Mark 4:40). 'Kleingelowiges' is 'n positiewe term, dit lê klem op die dissipels se geloof, hoewel dit nog verdere verdieping moet ondergaan. In dié verband is dit opmerklik dat ook die struktuur van die Matteusevangelie bydra om die 'leerbaarheid' van die dissipels te onderstreep. Tot en met Matteus 13 is die gehoor van Matteus gemeng, bestaande uit beide dissipels en skare, maar na Matteus 13:36 kom daar 'n wending. Hierna spits Jesus sy aandag hoofsaaklik toe op die dissipels, om hulle as die volgelinge wat reeds verstaan verder en vollediger te onderrig omtrent die geheime van die koninkryk. ${ }^{4}$

4.Dat Jesus volgens Matteus 13:36 weggaan van die skare en in die huis die verdere vrae van die dissipels beantwoord oor die betekenis van die gelykenis van die onkruid tussen die koring, kan as simbolies gesien word van Jesus se verdere toespitsing op die dissipels se onderrig (vgl. Ellis 1974:60) 
Die leergesag van die dissipels kan nog verder verbesonder word as die gesag om sondes te vergewe (vgl. Matt 6:14-15; 9:8; 12:32; 16:19 en 18:18; Overman 1990:130-133.) Wat in hierdie verband merkwaardig is, is dat waar hierdie gesag in Markus en Lukas uitsluitlik vir Jesus gereserveer word, dit deur Matteus na die dissipels uitgebrei word. Dit reflekteer iets van die selfverstaan van die Matteaanse gemeente. Vir hulle was die kerk parallel aan die koninkryk. Die gemeente verstaan homself as 'n ruimte waar die orde, struktuur en waardes van die heilige ruimte van die koninkryk uitgeleef word. Die klassieke uitdrukking hiervan vind ons in Matteus se weergawe van die Ons Vader-gebed in Matteus 6:10a-b, waar 6:10b uniek is aan Matteus. Lukas se weergawe bevat waarskynlik die oorspronklike bewoording, en sê bloot: 'Laat u koninkryk kom.' Matteus versag egter die streng eskatologiese gebed deur dit uit te brei met: 'soos in die hemel, so ook op die aarde.' Hiermee wil hy sê dat die kerk in der waarheid die koninkryk op aarde kan beliggaam. En juis daarom kan daar sulke ongewone gesag vir die Matteaanse kerk opgeëis word, deur byvoorbeeld sondes te vergewe.

Hierdie selfverstaan van die gemeente kom duidelik in Matteus 6:14-15 en 18:18 na vore. In beide hierdie gedeeltes word hemel en aarde met mekaar verbind deur die dissipels se optrede. As die dissipels ander se sondes vergewe, word dit ook deur die hemelse Vader vergewe (Matt 6:14-15). En in Matteus 18:18 word die formule 'bind en ontbind' en 'toesluit en oopsluit' vir dieselfde oogmerk ingespan: Wat die dissipels op aarde bind of ontbind, sal ook in die hemel gebind of ontbind wees. Die konteks van laasgenoemde gedeelte is kennelik dié van sondevergiffenis, soos Matteus 18:15-17 en 21 aandui. Die beslissing van die gemeente oor sondevergiffenis dra hemelse gesag. Wat op aarde of in die gemeente besluit word, word deur God in die hemel bekragtig.

In twee ander gedeeltes word hierdie gesag van die gemeente ook op 'n subtiele manier beskryf, te wete Matteus 12:32 en 9:8 (Overman 1990:132). In Matteus 12:32 gaan dit oor vergiffenis in geval van die sonde teen die Heilige Gees. Beide Markus en Lukas lê klem op die eskatologiese lot van die oortreder: hulle sal nie vergewe word nie. Maar Matteus voeg by: 'nóg in hierdie bedeling, nóg in die toekomstige bedeling.' Hierdeur word beklemtoon dat so 'n oortreder ook nóú, in hierdie lewe, gestraf sal word. En die bedoeling is waarskynlik dat die oordeel oor laasgenoemde deur die Matteaanse kerk gevel word. Oor Matteus 9:8 het ons reeds gehandel. Die resultaat kan hier net kortliks saamgevat word: By die genesing van die verlamde man en die vergewing van sy sondes was die omstanders verbaas oor die gesag wat aan mense toegeken word (hoewel dit Jesus was wat die handeling uitgevoer het). Die bedoeling is dat die omstanders nie soseer verbaas was oor die gesag om die man te genees nie, maar veral om sy sondes te vergewe. 'Mense' verwys hier waarskynlik na die verwondering by die Matteaanse gemeente dat aan hulle die 'mense' - die gesag gegee is om sondes te vergewe.

\section{Die aard van die gesag}

Tot sover is gelet op die gesagsoordrag aan die dissipels en die inhoud van daardie gesag. Vervolgens word aandag gegee aan die aard van die gesag: Met watter soort gesag tree die dissipels/leiers/Matteaanse gemeente op?

Die toonaard van die dissipels se gesag kan nie méér pregnant beskryf word as in Matteus 20:25-28 nie. Hier stel Jesus die dissipels se soort gesag op teenoor dié van die wêreld. By die wêreld se regeerders gaan dit oor naakte mag, baasspeel en magsmisbruik, maar by die dissipels mag dit nie so wees nie. Hy vervolg dan: 'Elkeen wat in julle kring groot wil word, moet julle dienaar wees; en elkeen wat onder julle die eerste wil wees, moet julle slaaf wees' (Matt 20:26b-27). En dan word Jesus se lewe as maatstaf geneem: 'Hy (Die Seun van die mens - HCvZ) het nie gekom om gedien te word nie, maar om te dien en sy lewe te gee as losprys vir baie mense' (Matt 28:28b) Hierdie woorde is nie uniek aan Matteus nie (dit word ook deur Markus en Lukas weergegee), maar dit kry binne die konteks van die Matteusevangelie 'n bepaalde betekenis. Matteus bind naamlik die gesag van die dissipels in 'n groter werklikheid in, naamlik gelykheid en diensbaarheid. Ons gee nou hieraan aandag.

Dat daar gesagsoordrag aan die dissipels plaasvind ten einde die woorde van Jesus gesagvol te interpreteer en selfs om op aarde sonde te vergewe, ly geen twyfel nie. Daarbý is reeds daarop gewys dat die aardse dissipels vanuit die perspektief van die Matteusverteller rolmodelle word vir die Matteaanse kerk - veral die leierskorps - van ongeveer vyftig jaar later. Indien dit as gegewe aanvaar word, kan tussen die reëls van die Matteusevangelie afleidings gemaak word omtrent die probleme wat in die kerk van Matteus voorgekom het. Een hiervan was waarskynlik 'n groeiende hiërargiese tendens. Dit blyk uit 'n gedeelte soos Matteus 23:8-12 - uniek aan Matteus - waar Jesus die dissipels maan om in teenstelling met die gebruik onder die Joodse skrifgeleerdes en Fariseërs hulleself nie 'rabbi/leermeester' (didaskalos), 'vader' (patēer) of 'leier/leermeeester' (kathēgētēs) te laat noem nie. Hierdie terme hou almal verband met die uitoefening van die leergesag in die gemeente. ${ }^{5}$ Hy herinner hulle daaraan dat hulle almal 'broers' (adelfoi) is. In sy teologisering oor die 'ampswerk' in die gemeente gaan Matteus dus antihiërargies te werk. Almal wat die leergesag wil uitoefen, moet weet dat die een nie bo die ander is nie, maar dat hulle gelyk is. Verder koppel Matteus die gedagte van gelykheid ook aan die diensmotief deur onmiddellik ná bogenoemde vermaning daarop te wys dat wie groot wil wees, bereid moet wees om die ander se dienaar (diakonos) te wees (Matt 23:11). Gelykheid en diens is verweef met mekaar en vorm die waarmerk of egtheidskenmerk van die uitoefening van die leergesag in die gemeente. Sonder hierdie waarmerk is gesag nie meer gesag in die Matteaanse sin van die woord nie.

Afgesien van wat reeds genoem is, word die hiërargiese of 'veramptelikingstendens' in die Matteaanse kerk op verskeie maniere deur Matteus teengewerk. Voorheen is die relatiewe uitsonderingsposisie van Petrus bespreek. Nou moet ook op die ander kant van die muntstuk gewys word, naamlik 5. Hierdie drie terme verwys waarskynlik nie na drie verskillende 'ampte' nie, maar is referensiële sinonieme wat na dieselfde funksie in die Matteaanse kerk verwys, naamlik onderrig (Van Zyl 1987:256). 
dat Petrus nie net die primus onder die dissipels is nie, maar veral die primus inter pares. Petrus se voorrangposisie word deur Matteus afgeskaal deurdat hy Petrus stewig in die dissipelkring anker. Byvoorbeeld, Petrus word nie meer spesiaal genoem in die aankondiging van die opstanding van Jesus, soos in Markus nie (Matt 28:7//Mark 16:7). Van beide Petrus en die ander dissipels word dieselfde dinge gesê: Die dissipels is ook geroep (Matt 4:18-22; 9:9); Petrus én die ander dissipels vra van Jesus die uitleg van 'n gelykenis (Matt 15:15; 13:36); beide bely Jesus as Seun van God (Matt 14:33; 16:16); beide word deur Jesus salig gespreek (Matt $16: 17 ; 13: 16-17)$; en beide is ontvangers van die Goddelike openbaring (Matt 16:17; 11:25; 13:11, 16-17) sowel as van die sleutelmag (Matt 16:19; 18:18). Verder is Petrus nie net tipies van die hoogtepunte nie, maar ook van die laagtepunte van dissipel-wees. Hy bely nie net vir Jesus nie, maar verloën Hom ook (Matt 26:70); hy loop nie net op die water nie, maar sink ook vanweë kleingeloof (Matt 14:31); hy is nie net ontvanger van die Goddelike openbaring omtrent Jesus se identiteit nie, maar is ook onkundig oor Jesus se lydensweg (Matt 16:23). Hoewel Petrus ' $n$ uitsonderingsposisie beklee (in $\S 5$ meer oor die implikasies hiervan), is daar geen verheerliking van sy persoon nie. Hy word in vele opsigte op gelyke voet gestel met die ander dissipels. Hy is nie net ' $n$ tipe van leierskap en gesagsuitoefening nie, maar ook van die lewe en stryd van elke gewone dissipel.

Ook die dissipelkring as geheel word op allerlei wyses daaraan herinner dat die voorreg van dissipel-wees geen bevoorregting inhou nie, maar dat hulle gelyk is aan mekaar en as sodanig transparant is vir die Matteaanse kerk. In 'n interessante artikel probeer Burnett (1983) vasstel wat die term palingenesia in Matteus 19:28 as na-pase verwysing vir die Matteaanse kerk sou inhou. Hy stel voor dat die term nie teen sy Stoïsynse agtergrond van die hergeboorte van die kosmos of individu verstaan moet word nie, maar binne sy huidige konteks wesenlik as 'n sinoniem vir die unieke Matteaanse uitdrukking 'einde van die wêreld' (sunteleia tou aiōnos) gesien moet word. So verwys dit na die toekomstige rol van die dissipels. Aan die einde van die wêreld, wanneer die Seun van die mens op sy troon sit, sal die dissipels wat Hom op aarde gevolg het, op twaalf trone sit en die twaalf stamme van Israel oordeel. Maar nie voor die tyd nie. In die huidige konteks staan die uitdrukking in verband met uitsprake van Jesus oor navolging, naamlik selfverloëning en opoffering. Dit is waar die swaartepunt lê. Daarom is Burnett van mening dat Matteus, deur klem te lê op die eskatologiese oordeelsfunksie van die dissipels, die gesagsonderskeidings in sy gemeente wou onderspeel. Die fokus moet op die regte plek lê in gemeenteverhoudings: nie op voortydige veroordeling nie, maar, by implikasie, op dissipelskap en diens aan mekaar.

Vanuit een van die sleuteltekste rondom gesagsoordrag is dit ook duidelik dat gesag en liefdesdiens vir Matteus hand aan hand gaan. In Matteus 18:15-17 het ons waarskynlik met 'n kerklike dissiplinêre prosedure uit die Matteaanse gemeente te doen, met die bevestiging in Matteus 18:18 dat die gemeente se handelinge hemelse sanksie geniet. Op sigself kan hierdie reëling egter rigied voorkom, en is dit vatbaar vir misbruik. Die manier waarop Matteus egter hierdie tradisie aanwend en kontekstualiseer binne Matteus 18 gee'n totaal ander karakter daaraan. Matteus plaas hierdie tradisie tussen die gelykenis van die verlore skaap (Matt 18:10-14) en die vraag na hoeveel keer my broer sal sondig en ek hom vergewe (Matt 18:21-35). Dit op sigself kleur die dissiplinêre handeling as iets wat nie daarop uit is om 'n lidmaat so gou as moontlik uit die gemeente te verwyder nie, maar as liefdevolle bemoeienis vanuit 'n gesindheid van vergewensgesindheid ten einde die lidmaat weer terug te wen vir die gemeente (Mathew 1985:123-124). Hierbenewens is daar ander aanduidings in Matteus 18 wat die hele hoofstuk merk as gemeentelike halakah wat uit 'n gesindheid van diensbaarheid spruit, waar die een die ander hoër ag as homself. So vra die dissipels in Matteus 18:1 die vraag oor wie die grootste is in die koninkryk van die hemele, waarop hulle die antwoord kry dat as jy nie verander en soos 'n kind (paidion) word nie, jy geen status in die koninkryk het nie. Waarop 'n gedeelte volg om die gemeente se sorg en diensbaarheid ten opsigte van die kleintjies (mikroi) wat in Jesus glo, uit te spel (Matt 18:6-9). Hierdie tema van gesindheidsverandering en uitreik na die geringe, tesame met die sleutelwoorde paidion, mikroi, en adelfos, maak van hierdie gedeelte ' $n$ tour de force in gemeentebediening waar gesag en diens op 'n unieke manier verbind word. Trouens, slegs wanneer gesag so uitgeoefen word, kan die dissipels of gemeente enigsins hoop op hemelse sanksie en op die teenwoordigheid van die verheerlikte Jesus in hulle midde (Matt 18:19-20).

Bogenoemde parameters waarbinne die leer- en dissiplinêre gesag van Petrus en die dissipels aangewend moet word, is tipies wat gebeur wanneer 'n tradisie wat vir 'n geloofsgemeenskap belangrik is, wel gekontinueer word maar terselfdertyd binne 'n nuwe teologiese verwysingsraamwerk nuut geïnterpreteer word sodat dit steeds bruikbaar kan bly. Powell (2003) neem byvoorbeeld die gesagsformule 'bind en losmaak', wat direk volg op die prosedure van Matteus 18:15-17 (18:18//16:19), en ondersoek die aanwending daarvan in Matteus. Hy kom tot die slotsom dat dit deur Matteus wel as een van die konstituerende elemente van die kerk se sending en lewe op aarde beskou is, maar dat dit sy krag ontvang vanuit 'n wyer konteks, naamlik Jesus se uitspraak dat Hy gekom het om die wet te vervul. Die vraag is dus: Wanneer is die kerk se oordeel oor en uitoefening van die leergesag bindend op lidmate? Bloot net wanneer hy 'n uitspraak maak omdat hy die gesag het? Nee, volgens Matteus is dit eers bindend wanneer die regte interpretasie van die wet van Moses gevolg word, dit wil sê, in ooreenstemming met Jesus se verstaan en vervulling daarvan. En in Matteus is daar' $n$ hele paar indikatore of riglyne wat hieroor vir die kerk koers en rigting kan gee, soos die goue reël (Matt 7:12), God se voorkeur vir barmhartigheid (Matt 9:13; 12:7), prioritisering van die liefde vir God en die naaste (Matt 22:34-40), en die identifisering van wat die swaarste weeg van God se wet, naamlik geregtigheid, barmhartigheid en betroubaarheid 
(Matt 23:23; Powell 2003:87). Eers wanneer hierdie riglyne nagekom word, kan aanvaar word dat kerklike oordele en optrede met Goddelike sanksie beklee is (Matt 18:18-20). En dit bring ons weer terug by die gedagte dat eers wanneer daar met ' $n$ gesindheid van selfverloëning in liefde uitgereik word na die geringes, kerklike optrede gewig dra.

Om uit te reik na die geringes is ook die manier waarop die gemeente wys dat hulle identifiseer met Jesus en sy sending. ${ }^{6}$ Die gelykenis van die eindoordeel in Matteus 25:31-46 illustreer hierdie gedagte treffend. Hier word die dissipels se reaksie op die nood van die wêreld, spesifiek die geringstes (elachistoi), as die toetssteen van ware dissipelskap gestel. Maar waarom is diens aan die geringstes diens aan Jesus? Omdat Jesus Hom met die geringstes identifiseer. In Matteus 25:40 noem Hy hulle 'my broers, die geringstes.' Hier lê waarskynlik 'n ryk Ou-Testamentiese agtergrond ingebed. Grassi (1981:83-84) wys daarop dat in die Ou Testament die uitleef van die wil van God ten nouste met die versorging van die weduwee, wese en vreemdeling saamhang (bv. Deut 10:12-13, 17-20). Verder, om die gebooie van God te onderhou, is nie in ' $n$ wettiese sin verstaan nie, maar as persoonlike diens aan God. In Matteus word Jesus gesien as die gesaghebbende interpreteerder van God se wet. Daarom, wie sy opdragte uitvoer, lewer 'n persoonlike diens aan Jesus en identifiseer met alles wat Jesus is en waarvoor Hy gekom het. En op sy beurt is Jesus die gehoorsame Seun van God. Dus, wie die opdragte van Jesus uitvoer, identifiseer met Jesus en so met God self, en bewys 'n diens aan Jesus en aan God. Dade van barmhartigheid, as dié uitdrukking van Jesus se aardse bediening, bring jou in direkte kontak met Hom en lewer die bewys dat jy sy gehoorsame seun is. Daarom is hulle wat barmhartigheid bewys het aan die geringstes, dikaioi (hulle doen die wil van God), en ontvang hulle die ewige lewe (Matt 25:46).

Slegs so verstaan die gemeente ook die visie van 'n universele dissipelskap wat Jesus aan die dissipels voorhou in Matteus 28:16-20. Dit is bekend dat Matteus 'n paradoksale 'sendingvisie' het. Aan die een kant is daar die beperkte sending aan die verlore skape van Israel (Matt 10:5-6; 15:24). Jesus bevestig ook hierdie gerigtheid op Israel deur te verklaar dat nie die kleinste lettertjie of letterstrepie van die wet verlore sal gaan nie, want Hy het nie gekom om die wet te verbreek nie, maar om dit te vervul (Matt 5:17-18). Aan die ander kant ontvang die dissipels in Matteus 28:19-20 die opdrag om dissipels van al die nasies te maak. En wat meer is, die besnydenis - dié merkteken van die Godsvolk - verval as inlywingsteken. In stede daarvan moet die nuwe dissipels gedóóp word. Hoe ver kan Jesus egter gaan om die wet op hierdie manier te vervul sonder om te breek met die Jodedom? Meier (1975:205) is van mening dat as werkshipotese vir Matteus aanvaar moet word 'n heilshistoriese skema van 'n aanvanklike beperkte bediening aan Israel wat ná die dood en opstanding van Jesus uitgebrei word tot die hele wêreld. Die dood en opstanding van Jesus vorm 'n eenheid en is as sodanig 'n apokaliptiese gebeure 6.Grams 2004:121 wys daarop dat 'ittleness' die aard én die taak van dissipelskap in die Matteusevangelie tipeer. (kyk die ander apokaliptiese tekens in Matt 27:51-54; 28:2-3) wat' $n$ totale wending in Jesus se bediening teweegbring. Nou val vorige geografiese, religieuse en etniese beperkings weg. In Matteus 28:16-20 het ons dus met 'n soort gerealiseerde eskatologie te doen waar die koninkryk van die hemel in hierdie werklikheid ingebreek het; alle mag behoort nou aan Jesus, dit is 'n soort proleptiese paroesie. Tog is dit nog nie die einde nie; die einde van die wêreld (sunteleia tou aiōnos, 'n unieke uitdrukking van Matteus) is nog uitstaande. Daarom is daar baie oorblywende gebreke wat noodsaak dat die nuwe dissipels moet konformeer aan alles wat Jesus onderrig het.

Punt is: die dissipels of Matteaanse kerk kan slegs deel in hierdie nuwe werklikheid van 'n sending-sonder-grense as hulle die gesag wat aan hulle oorgedra word, verstaan as selfopofferende diensbaarheid. Dit gaan nie meer net oor die verlore skape van Israel, oor eie gemaksones, oor 'posisies' en mag in die koninkryk van die hemele nie (Matt 18:3 [belangrikste in die koninkryk]; Matt 20:21 [sit aan die regterhand en linkerhand van Jesus]; Matt 20:25 [baasspeel en magsmisbruik]), maar daaroor om jou eie siening op te offer en ondergeskik te stel aan en te identifiseer met Jesus se visie vir die wêreld. Daarvoor het jy 'n ander mentaliteit, 'n ander gesindheid nodig. Jy ontvang gesag, ja, maar dis 'n gesag wat slegs in diensbaarheid en in totale oorgawe aan Jesus se visie kan realiseer.

\section{Interpretasie}

Om die uitsprake in Matteus oor die gesag van die dissipels na behore te begryp, moet dit geïnterpreteer word teen die agtergrond van die ontluikende Farisese Jodedom van die laat eerste eeu n.C. Dít was die konteks waarbinne die Matteaanse gemeente sy eie identiteit en gesag moes verstaan en posisioneer. ${ }^{7}$ Dit was 'n worsteling waarin die Matteaanse gemeenskap enersyds die Jesustradisie in terme van die Jodedom moes verstaan en verduidelik, maar andersyds hulle ook daarteen moes opstel en daaraan moes ontworstel.

Beide Jode en Jode-Christene was gewikkel in 'n identiteitskrisis ná die verwoestende gebeure van 70 n.C. Die Jode het die tempel in Jerusalem, die simbool van die interaksie tussen twee wêrelde - die Goddelike en die menslike - verloor, en moes hulle toenemend verlaat op hulle skrifgeleerdes om nuwe koers te gee vanuit die interpretasie van die wet van Moses. En die Jode-Christene, soos hulle in die Matteaanse gemeente manifesteer, was op die punt om geëkskommuniseer te word uit die sinagoge omdat hulle toenemend deur laasgenoemde beleef is as buite die grense van die Jodedom (Krentz 2004:24-25). ${ }^{8}$ Wat Matteus dus beskryf as die rol van Petrus en die dissipels kan mens sien as die antwoord van die Matteaanse ekklēsia aan die gesagsfigure van die Farisese sunagōgē (Hartin 1998:403).

7.Die ontstaansplek van die Matteusevangelie word deur die meeste geleerdes in Antiogië in Sirië geplaas. Overman (1990:158-159) plaas dit egter in Galilea. Die ontstaansplek is egter nie so belangrik nie. Wat wel belangrik is, is dat die ontstaansituasie gesien word as die Matteaanse gemeente in gesprek en in stryd met die Farisese Jodedom.

8.Stanton (1992:157) praat van die Matteaanse gemeente 'as a somewhat beleagured [sic] minority "sect" cut off from its roots'. 
Die oordrag van gesag aan Petrus en die dissipels, die klem op dié se leergesag en veral die gesag om sondes te vergewe, moet verstaan word as die interpretasie van een groep - in onderskeid van ander groepe - binne die Jodedom vir wie Jesus se interpretasie van die wet van Moses normatief geword het. Binne die opkomende Farisese Jodedom is die Fariseërs gesien as die gesaghebbende interpreteerders van die Joodse tradisies. Daarom het dit vir die Matteaanse gemeente nodig geword om hierteenoor 'n eie gesagsbasis te stel wat vir hulle dieselfde Joodse tradisies op 'n unieke manier kon interpreteer. En omdat die leergesag dominant was in die Farisese Jodedom was dit vanselfsprekend dat dít ook die klem sou dra in die Matteaanse gemeente. Soos reeds gestel (kyk $\S 2.3$ ), setel die leergesag in die persoon van Petrus. Overman (1990:139-140), op voetspoor van Max Weber, skets 'n situasie waar oordrag van gesag belangrik word in geval van die dood van 'n charismatiese leier (in hierdie geval Jesus). Oor tyd heen vervaag die herinneringe aan die charismatiese leier en ontstaan die vraag wie die leier se gesag kan voortsit. Die oorspronklike charismatiese gesag moet getransformeer en gelegitimeer word in die leier se opvolgers. So iets gebeur veral wanneer die leier iemand aanwys, asook deur direkte Godsopenbaring. En beide van hierdie sake is teenwoordig in die persoon van Petrus. Nie 'n mens nie, maar God self het aan Petrus die insig omtrent Jesus geopenbaar (Matt 16:17), en daarom kan Jesus hom aanwys as die gesagsbasis (rots en oordra van sleutelmag) van sy kerk (Matt 16:18-19). So is Petrus se gesag as gemeenteleier gelegitimeer en het dit ook in duidelike kompetisie gestaan tot ander soortgelyke aansprake, soos byvoorbeeld dié van die Fariseërs as outentieke interpreteerders van die Joodse leergesag. Petrus, sowel as die dissipelkring en dié se opvolgers, word so vir die Matteaanse gemeente die spreekbuis en beskermers van die outentieke leergesag van Jesus. En hoewel die Farisese leergesag, vreemd genoeg, nie heeltemal geïgnoreer mag word nie (vgl. Matt 23:2-3), mag hulle voorbeeld nie gevolg word nie. Vir die Matteaanse gemeente is die interpretasie en voorbeeld van Petrus en die dissipels normatief.

Op die voetspore van Petrus en die dissipels se gesag het 'n verdere gesagsinstansie in die Matteaanse gemeente na vore getree, naamlik hulle eie skrifgeleerdes. Matteus bevorder in sy Evangelie ' $n$ positiewer ingesteldheid teenoor hierdie groep. Hy doen dit op twee maniere (Hartin 1998: 399-400). Eerstens skep hy afstand tussen die skrifgeleerdes en die Fariseërs. Hy verwyder in baie gevalle die term 'skrifgeleerde' uit die Markaanse materiaal en voeg in of behou 'Fariseërs', bv Matteus 9:11; 12:24; 17:14; 21:23; 22:35; 26:3, 47 en 27:1. So identifiseer Matteus die Fariseërs as sy eintlike opponente (Overman 1990:115). Tweedens teken hy 'n uiters negatiewe prentjie van die Fariseërs. Hy wy 'n hele hoofstuk - Matteus 23 - hieraan. In geen onduidelike taal nie word hulle as skynheiliges uitgewys wat nie doen wat hulle predik nie. Weliswaar is die skrifgeleerdes hier saam met die Fariseërs onder skoot. Tog is dit duidelik dat die harde uitsprake eintlik gemik is teen die Fariseërs se skrifgeleerdes. Hoewel dit nie pertinent in Matteus 23 genoem word nie, sou mens dit kon aflei uit 'n vorige uitspraak van Matteus waar hy praat van 'hulle skrifgeleerdes' (Matt 7:28; Markus het 'die skrifgeleerdes'). Matteus maak dus 'n onderskeid tussen die skrifgeleerdes van die Fariseërs en dié van die Matteaanse gemeente (vgl. Luz 1985:416). ${ }^{9}$ Tekenend van hierdie positiewe beeld van die Matteaanse skrifgeleerdes is ook Matteus 13:52 - uniek aan Matteus - waar Matteus skrifgeleerdheid aan dissipelskap koppel. Wanneer 'n skrifgeleerde dissipel geword het, is hy in staat om telkens nuwe en ou dinge uit sy skatkamer te haal. Dit is ' $n$ beeld van die Matteaanse skrifgeleerde wat vanuit sy volgelingskap van Jesus die Joodse tradisies so interpreteer dat dit tot opbou en verryking van die gemeente dien, téénoor die Farisese skrifgeleerde wat die gemeenskap verkneg en belas (vgl. Matt 23:4).

Mens sou kon sê dat die prentjie wat die Matteusevangelie van die wedywering tussen Farisese Jodedom en Joodse Christendom skets, 'n vertekening van die werklikheid is. Want ongelukkig het ons nie Joodse tekste wat Matteus se weergawe van die situasie kan staaf nie. Martin (1996: 23-27) is daarom van mening dat die vermeende debat tussen die twee groepe histories as eensydige 'skeltaal' aan ons deurgegee word, slegs deur die oë van Matteus. Trouens, Matteus se weergawe is die debat; hy skep die debat met 'n doel - om die Jode te demoniseer en so verwydering tussen hulle en die Jode-Christene te veroorsaak. Die Matteusteks is soos wanneer 'n rebelse kind wil wegbreek uit die ouerhuis en dan 'n casus belli skep om sy wegbreek te regverdig en die skuld vir die verwydering volledig op die ouer te pak. Matteus se toe-eiening van die Joodse tradisies dien dan as 'n polemiese voertuig waardeur hy die morele hoë grond teenoor die Jode in sy omgewing wou bekom.

Martin is reg - natuurlik is Matteus besig om Jesus en die Matteaanse gemeente se gesag te bevorder teenoor die Farisese Jodedom. Maar wat waar is van Matteus, is waar van die hele Nuwe Testament. Daar is niks wat nie ideologies gekleur is nie. Alles in die Nuwe Testament dien om die gesag van Jesus en die vroeë kerk teenoor die wêreld te vestig, te bevorder en te verdedig. Dit is lank reeds aksioma onder Bybelkenners dat die Evangelies en die Nuwe Testament nie die bruta facta weergee nie, maar tendensieuse geskrifte is. Ons het die teologie van Matteus en die Nuwe Testament nie anders as in die vorm van ideologiese bevooroordeeldheid nie. Daarmee moet ons vrede maak. Maar dit beteken nie dat die waarheidsgehalte daarvan op losse skroewe gestel word nie. Die Nuwe-Testamentiese wetenskap doen immers ten minste twee dinge om hierdie ideologisering in perspektief te stel: (1) dit plaas hierdie geskrifte so goed moontlik met die metodes tot ons beskikking in historiese konteks; en (2), dit probeer om die inherente krag van die argumente en teologiese insigte so goed moontlik te verifieer en ter diskussie te stel.

9.In hierdie verband kan ook Matteus se polemiese gebruik van "hulle/julle sinagoge genoem word (Matt 4:23; 9:35; 10:17; 12:9; $13: 54 ; 23: 34)$. White (1991:215-217,
veral voetnoot 17) toon aan hoe hierdie formulering inpas by die Matteaanse veral voetnoot 17) toon aan hoe hierdie formulering inpas by die Matteaanse gemeente se worsteling om ' $n$ eie plek te vind te midde van die 'convulsions of an emerging new order' (White 1991:217) in die post 70 n.C. Jodedom. Tekenend van hierdie ontworsteling aan die Jodedom is ook Sisson (1997:566) se opmerking dat die gehoor van die Bergrede, en daarmee dié van die hele Matteus, ' $n$ JoodsChristelike subkultuur verteenwoordig wat nog nie volledig afgeskei het van die Jodedom nie, maar wat besig is om in daardie rigting te beweeg met hulle verstaan van Jesus se gesag. 
En myns insiens is die dialektiek tussen gesag en diens wat normaalweg uitsluitende begrippe is - juis een van die maniere waarop die Matteusevangelie self die uitwasse en misbruik van religieuse gesag enersyds relativeer en andersyds met nuwe inhoud en legitimiteit vul.

Mens sou dus kon vra: Watter appèl rakende religieuse gesag sou daar vir die eerste lesers vanuit die Matteusevangelie gegaan het? Ter Borg en Van Henten (2010) wys op die fyn nuanses van religieuse gesag - nie net op die misbruik daarvan nie, maar, positief, hoe dit op verskillende niveaus kan funksioneer. Dit kan troos, bemoedig, krag tot oorlewing verskaf, pyn en trauma sublimeer en transformeer, sonder institusionele vorme oorleef en gesag uitoefen, op 'n Stoïsynse manier stille protes aanteken, subversief opereer, ensovoorts. Matteus se anti-hiërargiese beklemtoning, sy fokus op gelykheid, op barmhartigheid, op die uitreik na en versorging van die geringes, op diensbaarheid en selfverloëning - tot op die punt van die opoffering van jou eie lewe - oefen 'n universeel religieuse appèl uit. In hierdie verband het Duling (1993:662-663) opgemerk dat die outeur van Matteus 'n marginal man is wat vir die leser ' $n$ voluntary marginality aanbied. Duling probeer Matteus se argument in sosiologiese kategorieë verpak en toon aan dat daar groepe in Matteus is wat destyds werklik gemarginaliseer was, soos die skare (ochloi), armes (ptōchoi), prostitute (pornai), eunugs (eunouchoi), ensovoorts, wat telkens deur Matteus as volgelinge van Jesus op die voorgrond gestoot word. Maar dan gebruik Matteus ook hierdie kategorieë om 'n vrywillige marginaliteit ${ }^{10}$ te bevorder. So is dit die armes van gees, die treurendes, die sagmoediges, dié wat honger en dors na geregtigheid, wat geseënd verklaar word (Matt 5:3-6). 'n Leefwyse van totale afhanklikheid van die Vader word as die ideaal voorgehou (Matt 6). Die ryk jongman (beslis nie 'n gemarginaliseerde nie) word aangemoedig om vrywillige armoede te aanvaar en ' $n$ volgeling van Jesus te word (Matt 19:21). Die siekes wat genees word en die evangelie wat aan die armes verkondig word (Matt 11:5, 'n aanhaling uit o.m. Jes 61:1-2) plaas die werk van Jesus aan die gemarginaliseerdes in die sentrum van sy messiaanse identiteit. En laastens, om nie meer te noem nie, die sentrale argument van hierdie artikel - dat die gesag van die dissipels 'n dienende gesag is onderstreep dat daar volgens Matteus ' $n$ vorm van religieuse gesag is wat oor groter legitimiteit beskik, wat'n dieper appèl het, wat 'n beter kans het op langtermyn volhoubaarheid, wat effektiewer transformerend op die samelewing inwerk, en wat nader aan die hart van God lê. Dít is die gesag wat Jesus, volgens Matteus, oordra aan sy dissipels en waarmee hulle die wêreld moet verower, en wat die leser vrywillig op hom moet neem.

\section{Erkennings \\ Mededingende belange}

Die outeur verklaar dat hy geen finansiële of persoonlike verbintenis het met enige party wat hom nadelig kon beïnvloed in die skryf van hierdie artikel nie.

10.Carter (1997) wy 'n hele artikel daaraan om aan te toon hoe Matteus die eienskappe van die bios-genre meng met ander genres, byvoorbeeld encomium, om die Matteaanse gemeente as 'n marginale gemeenskap te bevorder.

\section{Literatuurverwysings}

Brooks, O.S. (sr.), 1981, 'Matthew xxviii 16-20 and the design of the First Gospel', Journal for the Study of the New Testament 10, 2-18. http://dx.doi. org/10.1177/0142064X8100301001

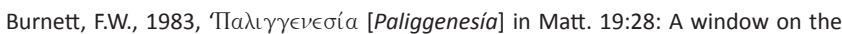
Matthean community?', Journal for the Study of the New Testament 17, 60-72. http://dx.doi.org/10.1177/0142064X8300501708

Carson, D.A., 1984, 'Matthew', in F.E. Gaebelein (ed.), The Expositor's Bible Commentary, p. 370, vol. 8, Zondervan, Grand Rapids.

Carter, W., 1997, 'Community definition and Matthew's Gospel', Society of Biblical Literature Seminar Papers, 637-663.

Duling, D.C., 1993, 'Matthew and marginality', in Lovering, pp. 642-671.

Edwards, J.R., 1987, 'The use of MPOLEPXE $\triangle \Theta A$ A [PROSERCHESTHAl] in the Gospel of Matthew', Journal of Biblical Literature 106(1), 65-74. http://dx.doi. org/10.2307/3260554

Ellis, P.F., 1974, Matthew: His mind and message, Liturgical Press, Collegeville.

Grams, R.G., 2004, "Not "leaders" but "little ones" in the Father's kingdom: The character of discipleship in Matthew's Gospel', Transformation 21(2), 114-125.

Grassi, J.A., 1981, “'I was hungry and you gave me to eat." (Matt. 25:35ff.) The divine identification ethic in Matthew', Biblical Theology Bulletin 11(3), 81-84. http:// dx.doi.org/10.1177/014610798101100305

Hartin, P., 1998, 'Disciples as authorities within Matthew's Christian-Jewish community', Neotestamentica 32(2), 389-404.

Keener, C. S., 1999, A Commentary on the Gospel of Matthew, Eerdmans, Grand Rapids.

Kingsbury, J.D., 1979, 'The figure of Peter in Matthew's Gospel as a theological problem' Journal of Biblical Literature 98, 67-87. http://dx.doi.org/10.2307/3265912

Krentz, E., 2004, 'Missionary Matthew: Matthew 28:16-20 as summary of the Gospel', Currents in Theology and Mission 31(1), 24-31.

Lee, K., 2010, 'Matthew's community and the Gentile mission', PhD thesis, Department of New Testament, North-West University.

Lovering, E.H. (ed), 1993, Society of Biblical Literature: 1993 Seminar Papers, Scholars Press, Atlanta.

Luz, U., 1980, 'Die Jünger im Matthäusevangelium' in J. Lange (Hrsg.), Das Matthäusevangelium, pp. 377-415, Wissenschaftliche Buchgesellschaft, Darmstadt. (Wege der Forschung 525.)

Luz, U., 1985, Das Evangelium nach Matthäus (Mt 1-7), Benzinger/Neukirchener Verlag, Zürich/Neukirchen-Vluyn. (EKK I/1.)

Luz, U., 1995, The theology of the Gospel of Matthew, Cambridge University Press, Cambridge. (New Testament Theology.)

Luz, U., 1996, Das Evangelium nach Matthäus (Mt 8-17), Benzinger/Neukirchener Verlag, Zürich/Neukirchen-Vluyn. (EKK I/2.)

Martin, R.T., 1996, 'Ideology, deviance, and authority in the Gospel of Matthew: The political functioning of performative writing', Literature \& Theology 10(1), 20-32. http://dx.doi.org/10.1093/litthe/10.1.20

Mathew, P.K., 1985, 'Authority and discipline: Matt. 16.17-19 and 18.15-18 and the exercise of authority and discipline in the Matthean community', Communio Viatorum 28(3/4), 119-125.

Meier, J.P., 1975, 'Salvation history in Matthew: In search of a starting point', Catholic Biblical Quarterly 37, 203-215.

Overman, J.A., 1990, Matthew's Gospel and formative Judaism: The social world of the Matthean community, Fortress Press, Minneapolis.

Perkins, P., 1993, 'Matthew 28:16-20: Resurrection, ecclesiology and mission', in E.H. Lovering (ed), Society of Biblical Literature: 1993 Seminar papers, pp. 574-588, Scholars Press, Atlanta.

Powell, M.A., 2003, 'Binding and loosing: Asserting the moral authority of Scripture in light of a Matthean paradigm', Ex Auditu 19, 81-96.

Reese, J., 1977, 'How Matthew portrays the communication of Christ's authority', Biblical Theology Bulletin 7(2), 139-144. http://dx.doi. org/10.1177/014610797700700305

Sisson, R.B., 1997, 'Voices of authority in the Sermon on the Mount', in Society of Biblical Literature: Seminar Papers no. 36, pp. 551-566, Scholars Press, Atlanta.

Smith, R. H., 1993, 'Matthew 28:16-20, Anticlimax or key to the Gospel?', in E.H. Lovering (ed), Society of Biblical Literature: 1993 Seminar papers, pp. 589-603, Scholars Press, Atlanta.

Society of Biblical Literature, 1997 Seminar Papers, Scholars Press, Atlanta.

Stanton, G.N., 1992, A Gospel for a new people: Studies in Matthew, T\&T Clark, Edinburgh.

Ter Borg, M.B. \& Van Henten, J.W., 2010, 'Introduction', in M.B. Ter Borg \& J.W. van Henten (eds.), Powers: Religion as a social and spiritual force, pp. 1-22, University Press, Fordham.

Van Zyl, H.C., 1987, 'Matteus 18:15-20: 'n Diachroniese en sinchroniese ondersoek met besondere verwysing na kerklike dissipline', DD proefskrif, Departement Nuwe Testament, Universiteit van Pretoria.

White, L.M., 1991, 'Crisis management and boundary maintenance: The social location of the Matthean community', in D.L. Balch (ed.), Social history of the Matthean community: Cross-disciplinary approaches, pp. 211-247, Fortress Press, Minneapolis. 